(RESEARCH ARTICLE)

\title{
Evaluation of anthelmintic activity of Amomum subulatum fruits extract
}

\author{
Khursheed Alam ${ }^{1,}{ }^{*}$, Devender Pathak ${ }^{2}$, Vandana Arora Sethi ${ }^{1}$ and Quaisul Hoda ${ }^{1}$ \\ ${ }^{1}$ Lloyd Institute of Management and Technology (Pharm), Plot No.-11, Knowledge Park-II, Greater Noida, Uttar Pradesh- \\ 201306, India. \\ ${ }^{2}$ Pharmacy College, UP University of Medical Sciences, Saifai, Etawah, Uttar Pradesh-206130, India.
}

Publication history: Received on 31 July 2020; revised on 13 August 2020; accepted on 15 August 2020

Article DOI: https://doi.org/10.30574/wjarr.2020.7.2.0287

\begin{abstract}
Several species of the genus Amomum yield fruits which are usually much larger in size but less aromatic. Amomum aromaticum and Amomum kepulaga yield Bengal cardamoms (Bari Ilayachi) and round or cluster cardamoms respectively. Their seeds are generally adulterated with the authentic drug. Another drug which is known by the name small cardamom consists of the dried ripe fruits of Elettaria cardamomum, which is small in size, green to pale buff in colour, the seeds of which are removed as and when required for use.Helminthes have a complex life cycle, often involving several species. In human infection by helminthes may occur in many ways, and poor hygiene is a major contributory factor. Many enter by mouth from unpurified drinking water or in badly cooked meat from infected animals or fish.The present study is an attempt to explore the anthelmintic activity of ethanolic extract of fruits of Amomum subulatum. Family-Zingibreaceae. Various doses of ethanolic extracts were evaluated for their anthelmintic activity on adult Indian earthworms, Pheretima posthuma. All extracts were able to show anthelmintic activity at $10 \mathrm{mg} / \mathrm{mL}$ concentration. The activities are comparable with the standard drugs, piperazine citrate and albendazole. All the doses of ethanolic extract of Amomum subulatum showed dose dependent anthelmintic activity in comparison to standard drugs. The data were found statistically significant by using one way Anova at $5 \%$ level of significance ( $\mathrm{p}<$ 0.05).
\end{abstract}

Keywords: Albendazole; Amomum subulatum; Anthelmintic; Piperazine citrate; Zingiberaceae

\section{Introduction}

Amomum subulatum (Family- Zingiberacea) is a tall, perennial plant, with leafy stems, up to $2.5 \mathrm{~m}$ in height, leaves oblong-lanceolate, acuminate, glabrous, spikes globose, very dense, shortly peduncled [1], cultivated in swampy places in Bengal, Sikkim, Assam and Tamil Nadu [2], fruit is large, coarsely striated dark brown in colour, measuring 2-3 cm in length and up to $1.5 \mathrm{~cm}$ in width. It is a triocular capsule, anterio-posteriorly flattened, having a number of irregular, dentate- undulate wings which extend from the apex downwards for two third of its length, internally the capsule contains several seeds held together by a viscous pulp of dark brown colour [3]. Oil extracted from the seeds is aromatic, stimulant, stomachic, applied to eyelids to allay inflammation [4]. Decoction of seeds is used as a gargle in affections of the teeth and gums. In combination with the seeds of melon it is used as a diuretic in cases of gravel of the kidneys [5]. Seeds are also used in gonorrhea and as an aphrodisiac. They have been also found useful in neuralgia in large doses [6].

Literature survey revealed that no systematic study has been reported for its anthelmintic activity. So, present study was carried out to findout the anthelmintic activity of the fruits of Amomum subulatum.

\footnotetext{
* Corresponding author: Khursheed Alam

Lloyd Institute of Management and Technology (Pharm), Plot No.-11, Knowledge Park-II, Greater Noida, Uttar Pradesh-201306, India
} 


\section{Material and methods}

\subsection{Plant collection and authentication}

The fruits of Amomum subulatum were collected from the local market in Delhi and were authenticated by Dr. H. B. Singh, Scientist Incharge, NISCAIR, New Delhi. A voucher specimen NISCAIR/RHMD/CONSULT/-2007-08/855/39 was preserved for future reference.

\subsection{Worms collection and authentication}

Pheretima posthuma worms were collected from the water logged areas of the soil and identified, washed with water to remove dirty matter.

\subsection{Preparation of Plant extract}

In the present study, the ethanolic extract of air-dried fruit powdered material (500 g) was prepared using soxhlet apparatus, concentrated and dried using Buchi rotavapour, it gives a brownish mass (56.64 g). The powdered material (500 g) was percolated with cold water to get the aqueous extract ( $31.42 \mathrm{~g})$. The dried ethanolic and aqueous extracts were stored in a desiccator to carry out phytochemical and pharmacological studies. Each extract was subjected to qualitative chemical investigation of phytoconstituents such as alkaloids, flavonoids, tannins, carbohydrates, proteins, vitamins, coumarins etc.

\subsection{Preliminary phytochemical investigation of Amomum subulatum fruits}

The ethanolic extract of fruit was subjected to qualitative chemical investigation for the identification of different phytoconstituents like alkaloids, glycosides, sterols, saponins, carbohydrates, tannins, proteins, triterpenoids. Preliminary phytochemical screening was performed using the standard procedures [7]. The presence of phytoconstituents such as glycosides, phenolic compounds, flavonoids, carbohydrates, tannins, proteins, amino acids, steroids and volatile oil were confirmed as shown in Table 1.

Table 1 Preliminary phytochemical screening for the ethanolic extract of fruit of Amomum subulatum.

\begin{tabular}{lll}
\hline S. No & Phytochemical test & Result of the test \\
\hline 1. & Alkaloids & -- \\
2. & Glycosides & + \\
3. & Phenolic compounds & + \\
4. & Sterols & + \\
5. & Flavonoids & + \\
6. & Saponins & -- \\
7. & Carbohydrates & + \\
8. & Tannins & + \\
9. & Resins & -- \\
10. & Proteins and Amino acids & + \\
11. & Volatile oils & + \\
\hline
\end{tabular}

\subsection{Biological study}

Healthy adult Indian earthworm (Pheretima posthuma), due to its anatomical and physiological resemblance with the intestinal round worm parasites of human beings were used in the present study [8-10]. All earthworms were of equal size. They were collected from local place, washed and kept in water. 


\subsection{Drugs}

The ethanolic extract of Amomum subulatum was tested in various doses in each group. Normal saline water was used as control. Piperazine citrate and albendazole were used as standard drugs for comparative study with ethanolic extracts.

\subsection{Experimental method}

The method of Pathak [11] was followed for screening of anthelmintic activity. Anthelmintic activity was evaluated on adult India earthworm, Pheretima posthuma. Earthworms were divided into nine groups (5 each). The first group (I) served as normal control which received saline water only. The second (II) and third (III) groups received the standard drugs piperazine citrate and albendazole at a dose level of $10 \mathrm{mg} / \mathrm{ml}$. Groups (IV) to (IX) received doses of ethanolic extracts of $10 \mathrm{mg} / \mathrm{ml}, 15 \mathrm{mg} / \mathrm{ml}, 20 \mathrm{mg} / \mathrm{ml}, 25 \mathrm{mg} / \mathrm{ml}, 30 \mathrm{mg} / \mathrm{ml}, 35 \mathrm{mg} / \mathrm{ml}$ respectively. Observations were made for the time taken to cause paralysis and death of individual worms for $02 \mathrm{~h}$. Paralysis was conformed when the worms did not revive even in normal saline water. Death was concluded when the worms lost their motility followed by fading away of their body colours.

Table 2Anthelmintic activity of ethanolic extracts of Amomum subulatum, piperazine citrate (Standard-1) and albendazole (Standard-2).

\begin{tabular}{|c|c|c|c|c|}
\hline Group & Treatment & Dose $(\mathrm{mg} / \mathrm{mL})$ & $\begin{array}{l}\text { Time taken for } \\
\text { paralysis (min) } \\
(X \pm \text { S.D) }\end{array}$ & $\begin{array}{l}\text { Time taken for } \\
\text { death (min) } \\
\text { (X } \pm \text { S.D.) }\end{array}$ \\
\hline I & Control (Normal saline) & $\cdots$ & $\cdots \cdot$ & $\ldots \ldots$. \\
\hline II & $\begin{array}{l}\text { Standard-1 } \\
\text { (Piperazine citrate) }\end{array}$ & 10 & $27.3 \pm 0.31$ & $45.5 \pm 0.82$ \\
\hline III & $\begin{array}{l}\text { Standard-2 } \\
\text { (Albendazole) }\end{array}$ & 10 & $25.4 \pm 0.63$ & $38.6 \pm 0.63$ \\
\hline IV & Ethanolic extract & 10 & $34.1 \pm 0.42$ & $50.3 \pm 0.78$ \\
\hline V & Ethanolic extract & 15 & $31.5 \pm 0.01$ & $47.5 \pm 0.65$ \\
\hline VI & Ethanolic extract & 20 & $26.3 \pm 0.21$ & $40.2 \pm 0.08$ \\
\hline VII & Ethanolic extract & 25 & $24.0 \pm 0.34$ & $30.1 \pm 0.56$ \\
\hline VIII & Ethanolic extract & 30 & $22.1 \pm 0.52$ & $26.0 \pm 0.72$ \\
\hline IX & Ethanolic extract & 35 & $20.2 \pm 0.78$ & $24.2 \pm 0.41$ \\
\hline
\end{tabular}

Each value is represented as mean \pm standard deviation $(n=5)$, standard error mean $<0.492$, data are found to be significant by testing through oneway Anova at $5 \%$ level of significance $(\mathrm{P}<0.05)$.

\subsection{Data analysis}

The data on biological studies were reported as mean \pm standard deviation $(n=5)$. For determining the statistical significance, standard error mean and analysis of variance (Anova) at $5 \%$ level significance was employed. P values < 0.05 were considered significant [12].

\section{Results and discussion}

The ethanolic extracts of Amomum subulatum produced a significant anthelmintic activity in dose dependent manner as shown in Table 2. Normal saline water was used as control. The activity shown by ethanolic extracts is of considerable importance. All data were found to be statistically significant at $5 \%$ level of significance $(\mathrm{P}<0.05)$ when subjected to one-way ANOVA. The extent of activity shown by the crude extracts was found to be dose dependent and same effect as that of $10 \mathrm{mg} / \mathrm{ml}$ of piperazine citrate was seen in $20-35 \mathrm{mg} / \mathrm{ml}$ of ethanolic extract, and same effect as that of $10 \mathrm{mg} / \mathrm{ml}$ of albendazole was seen in $25-35 \mathrm{mg} / \mathrm{ml}$ of ethanolic extract. Fig 1.

The anthelmintic activity of the ethanolic extract was comparable with that of standard drugs. Albendazole and piperazine are used as anthelmintic drugs, but these drugs show some unwanted effects like gastrointestinal 
disturbance, urticaria and bronchospasm and some patients experienced dizziness, paraesthesias, vertigo and in coordination. These drugs are also contraindicated in pregnant women and to those with compromised renal and hepatic function.

If we formulate anthelmintic drug from Amomum subulatum fruits probably this will show no unwanted effects, because the herbal formulations generally are safe, natural and have little or no side effects and as a raw material for the preparation of the formulation which is easy available with low cost. More work is needed to identify the main active principles which are responsible for the anthelmintic activity.

In order to assess the mechanism of action of the extract, its effect was tested on worms (Pheretima posthuma). Anthelmintic drugs like albendazole and piperazine citrate act by reversibly inhibiting neuromuscular transmission in the worm, probably by acting like GABA, the inhibitory neurotransmitter or GABA-gated chloride channels in nematode muscle that causes relaxation and depresses responsiveness to contractile action of Ach. Flaccid paralysis of the worms followed by death occurs $[13,14]$. The fact that the extract of Amomum subulatum also shows paralysis in worms followed by death suggests that it may act like albendazole.

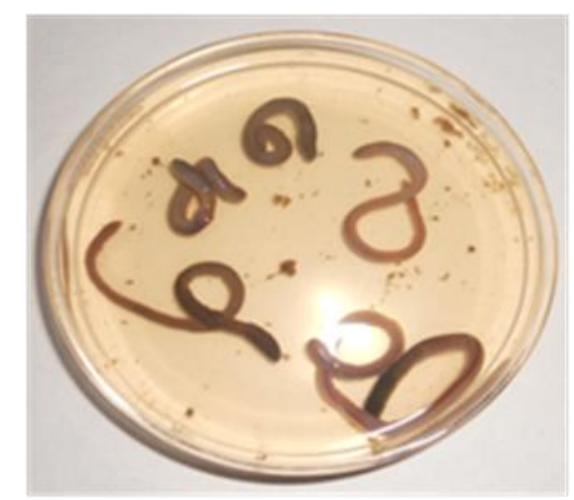

A

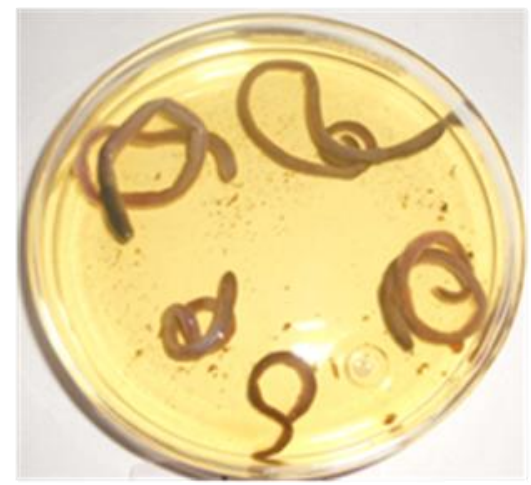

B

Figure 1Anthelmintic studies against earthworms A- Dead Earthworm, B-Paralysed Earthworm

\section{Conclusion}

It could be concluded that the ethanolic extract of fruits of Amomum subulatum is having anthelmintic activity, compared to the standard drugs which is a significant result. Further studies are required to identify the actual chemical constituents that are present in the plant which are responsible for anthelmintic activity.

\section{Compliance with ethical standards}

\section{Acknowledgments}

Dr. Mohmmad Mujeeb, Professor, Department of Pharmacognosy and Phytochemistry, Jamia Hamdard, New Delhi for providing general support and encouragement, Dr. H. B. Singh, Scientist Incharge, NISCAIR, New Delhi, for providing valuable information about the plant and its identification.

\section{Disclosure of conflict of interest}

This research article is for academic purpose only. No conflict of interest was reported by the authors.

\section{References}

[1] Anonymous. (2000). Wealth of India- Raw Material, Vol-I, CSIR, New Delhi, 227-229.

[2] Khare CP. (2007). Indian Medicinal Plants, An Illustrated Dictionary, $1^{\text {st }}$ ed., Springer, 44.

[3] Sarim YK. (1996). Illustrated manual of Herbal Drugs used in Ayurveda, CSIR and ICMR, 280. 
[4] Chopra RN, Nayer SL and Chopra IC. (1992). Glossary of Indian Medicinal Plants, CSIR, $1^{\text {st }}$ ed, 15.

[5] Nandkarni AK. (1982). Indian Materia Medica, $3^{\text {rd }}$, ed., Bombay Popular Prakashan, 1, 93-94.

[6] Kirtikar KR and Basu BD. (1987). Indian Medicinal Plants, $2^{\text {nd }}$ ed., Vol-IV, International Book Distributors and Publisher, 2431-2433.

[7] Harborn JB. (1988). Phytochemical methods, $3^{\text {rd }}$ ed. Chapman and Hall, London, 117-119.

[8] Vidyarthi RD. (1977). A Textbook of Zoology, Chand and Co. Press, New Delhi, 14th ed, 329.

[9] Thron GW. (1977). Harrison's Principles of Internal Medicine, Mc Grew Hill, New York, 1088.

[10] Vigar Z. (1984). Atlas of Medicinal Parasitology, Publishing House, Singapore, $2^{\text {nd }}$ ed, 216.

[11] Ansari SH, Alam K and Pathak D. (2010). Evaluation of Anthelmintic activity of Adhatoda zeylanica Medic. Leaves extract. Indian Drugs, 47(10), 55.

[12] Bolton S. (1997). In: Pharmaceutical Statistics- Practical and Clinical Applications, Marcel Dekker, New York, 69.

[13] Rang HP and Dale MM. (2007). Textbook of Pharmacology, Churchill Livingstone, Elsevier, $6^{\text {th }}$ ed, 712.

[14] Tripathi KD. (2008). Essential of Pharmacology, Jaypee Brothers Medical Publishers (P) LTD, $6^{\text {th }}$ ed, 808. 